\title{
Multi-Criteria Computer Aided System for Industrial Machines' Performance Assessment
}

\author{
Olasoji Rasak Olagunju, Basil Olufemi Akinnuli, Pius Bamidele Mogaji, \\ Olayinka 0. Awopetu
}

Department of Industrial and Production Engineering, Federal University of Technology, Akure, Nigeria

Email: ifembola@yahoo.com

How to cite this paper: Olagunju, O.R., Akinnuli, B.O., Mogaji, P.B. and Awopetu, O.O. (2020) Multi-Criteria Computer Aided System for Industrial Machines' Performance Assessment. Open Access Library Journal, 7: e6862.

https://doi.org/10.4236/oalib.1106862

Received: September 25, 2020

Accepted: November 17, 2020

Published: November 20, 2020

Copyright $\odot 2020$ by author(s) and Open Access Library Inc.

This work is licensed under the Creative Commons Attribution International License (CC BY 4.0).

http://creativecommons.org/licenses/by/4.0/

\section{(c) (i) Open Access}

\begin{abstract}
Efforts have been made by some researchers to determine machines' economic performance, some considered engineering features, some supply conditions while some look into the productivity as well as profitability of the machine separately. Recently, [1] saw the performance assessment of machine as surrogate problem and they deviate from single strategic decision common in past researches to multi-criteria approach in their research. Considerations were given to: annual operation cost, machine effectiveness and cost effective index as strategic decisions for machine performance evaluation. The model was robust, well integrated but its application is time consuming for decision making. There is no software to address this multi-criteria surrogate problem yet. Available single strategic decision software was of high cost, hence the development of this software that is flexible and novel to proffer solution to this problem using JAVA programming language. The software performance was evaluated using the data gotten from [1]. The summary of each year performance of a case study of cocoa winnowing machine on each of the selected strategic decision from 2008 to 2017, as it affects the machine annual operating cost (MAOC), overall machine effectiveness (MEFF) and cost effective index (CEI), was shown in Table 2. That of the year 2008 was 226,061.365; 0.97; and 0.99 for AOC; MEFF and CEI respectively. These results were statistically analysed and the results' graphs were shown in Figures 2-5, and Figure 6, respectively. Their results were compared with the results of the software developed and the results were $100 \%$ accurate since there was no deviation from the results. Availability of this software makes the developed multi-criteria machine performance assessment model useable anywhere in the world.
\end{abstract}




\section{Subject Areas}

Industrial Engineering

\section{Keywords}

Modeling, Strategic Decision, Multi-Criteria Features, Software Development, Performance Evaluation

\section{Introduction}

\subsection{Background}

The need to explore information and computer technology to solve agricultural problem most especially in agro-oil machines in industries become so important when the trend in computer world is increasing. The development in Information Computer Technology (ICT) can be applied to material processing industries in other to improve the effectiveness, quality and productivity of the processing machinery. This study was motivated by the recent emergence and growth of the computer in our society into which our processing industries must integrate.

\subsection{Literature Review}

When evaluating the performance of processing machine, two separate approaches can be taken: processing machines follow established principles that describe their operating characteristics on a generic basis and calculations of power, efficiencies, etc. are easily calculated using simple equations governing those properties [2] [3] [4] [5]. In other to evaluate machine performance, a holistic approach was suggested by several studies [6] [7] [8] [9] and [10]. By collecting data from the operations of processing machines, operator behaviour and skill level [9], and economic factors related to processing industries [6] were determined on a much broader scale than with traditional theory based research.

Effective optimization model development is essential for processing equipment. This enhances the repair and maintenance of equipment at the most appropriate time [11]. It is being used in the developed world to know the salvage life of the machine, when you need to change the machine, the time to carry out certain periodic maintenance and repair. This also helps in determining the degree of utility of the equipment [12]. Important factors including types of equipment and operations are to be considered.

Optimization techniques such as linear or non-linear programming that minimize cost subject to reasonable constraints (e.g., labour availability, frost dates) can help improve profitability [12]. Over the decades, industries and their organization concentrated most of their attention upon products production thereby ignoring the "Overall Machine Effectiveness" (OEE) factors, viewing it as a 
necessary evil. [13] and [14] said, today, with the general operating cost rising each year, there is the potential of realizing significant savings if industrial optimization managers adhere strictly to proper OEE analysis practices. [15] said a well-structured OEE metrics practice plays a vital role in the efficiency, development and progress of manufacturing/processing industries.

A computer program is an instance, or concrete representation, for an algorithm in some programming language [16] [17]. Once we have a correct algorithm for a problem, we have to determine the efficiency of that algorithm. This view is stated very succinctly in the well-known slogan "algorithm = data structure + control" [18].

Some of the related works done so far in this area of study are hereby summarized in Table 1. Hundreds of high level programming languages have been developed, the most common ones were shown in Table 2 for good comparison under ten criteria.

\section{Methodology}

The method applied to achieve the set objectives of this research involves: identification of the strategic decisions and their attributes; adopting the model developed by [1] as well as its logic. The computer algorithm and its software were developed, application of the developed software using data of [1], on winnowing machine of cocoa industry as case study, results of the developed software were evaluated by comparing it with the manually generated results for its performance evaluation.

\subsection{Models Development for Machine Annual Operating Cost}

The models developed for the strategic decisions were: machine annual operating/running cost, overall machine effectiveness and machine cost effective index.

\subsubsection{Machine Annual Operating/Running Cost $\left[\dddot{O}_{c}\right]$}

This is the financial economic consideration required to run the processing machine throughout the year. The model was as shown in Equation (1).

$$
\left[\dddot{O}_{c}\right]=F e \% P+H\left(R M_{c}+L+O+F+T\right)
$$

\subsubsection{Overall Machine Effectiveness $[\ddot{A}]$}

This is the capability of producing a desired result. The three major attributes for its determination are machine availability, $[\tilde{A}]$ performance efficiency $[\dot{\eta}]$ and rate of quality product $\left[\phi_{r}\right]$. The mathematical model required is shown in Equation (2),

$$
[\ddot{A}]=\tilde{A} \times \ddot{\eta} \times \phi_{r}
$$

\subsubsection{Cost Effectiveness Index $\left(W_{c}\right)$}

It also shows machine's ability to fight inflation. 
Table 1. Previous works on cocoa processing and machinery and software development.

\begin{tabular}{|c|c|c|c|}
\hline S/N & Names/Years & Job Description & Contributions/Remark \\
\hline [19] & Akinnuli et al. (2014) & $\begin{array}{l}\text { Computer Aided Design for Cocoa Beans } \\
\text { Processing Yield Prediction. }\end{array}$ & $\begin{array}{l}\text { Model developed focused on cocoa beans, } \\
\text { butter and cake yield predictions for any } \\
\text { quantity of cocoa beans pressed. }\end{array}$ \\
\hline [20] & Akinnuli et al. (2015) & $\begin{array}{l}\text { Design concepts towards mechanization } \\
\text { of cocoa beans winnowing process. }\end{array}$ & $\begin{array}{l}\text { Design and analysis of required winnowing } \\
\text { machine components, }\end{array}$ \\
\hline [21] & Adzimah et al. (2010) & Design of cocoa pod splitting machine. & $\begin{array}{l}\text { Cocoa pod splitting machine } \\
\text { was fabricated. }\end{array}$ \\
\hline [22] & Arai and Iwata, (1992) & $\begin{array}{l}\text { Product Modeling system in conceptual } \\
\text { design of mechanical products. }\end{array}$ & Model of mechanical products. \\
\hline [23] & Audu et al. (2014) & $\begin{array}{l}\text { Development of a concentric cylinder } \\
\text { locust beans dehuller. }\end{array}$ & $\begin{array}{l}\text { A concentric cylinder dehuller } \\
\text { for locust was developed. }\end{array}$ \\
\hline [24] & Awua, (2002) & $\begin{array}{l}\text { Cocoa Processing and chocolate } \\
\text { manufacture in Ghana. }\end{array}$ & $\begin{array}{l}\text { Review of how cocoa bean is being } \\
\text { processed in Ghana. }\end{array}$ \\
\hline [25] & Bjarnemo et al. (1998) & $\begin{array}{l}\text { Shortcomings of Computer Aided Design } \\
\text { Systems in conceptual design. }\end{array}$ & $\begin{array}{l}\text { Inadequacies of Computer Aided Design } \\
\text { Systems in conceptual design. }\end{array}$ \\
\hline [26] & Bozzo et al. (1998) & $\begin{array}{l}\text { Application of qualitative reasoning } \\
\text { in Engineering. }\end{array}$ & Qualitative reasoning in Engineering. \\
\hline [27] & EEC (1973) & $\begin{array}{l}\text { Directive } 73 / 241 \text { EEC by European parliament } \\
\text { and the European Council relating to cocoa } \\
\text { and chocolate products intended for human } \\
\text { consumption. }\end{array}$ & $\begin{array}{l}\text { Examination of cocoa and chocolate } \\
\text { products consumed by human by } \\
\text { European Parliament and } \\
\text { European Council. }\end{array}$ \\
\hline [28] & Faborode and Oladosu (1991) & $\begin{array}{l}\text { Development of a cocoa pod } \\
\text { processing machine. }\end{array}$ & $\begin{array}{l}\text { Ccocoa pod machine was developed and } \\
\text { performance evaluation was carried out on it. }\end{array}$ \\
\hline [28] & Harrington (1998) & $\begin{array}{l}\text { Development of software tools for } \\
\text { automation and acceleration of the } \\
\text { engineering design process. }\end{array}$ & $\begin{array}{l}\text { Model developed was used for automation } \\
\text { and acceleration of engineering } \\
\text { design process. }\end{array}$ \\
\hline [30] & http://www.worldcocoafoundation.org & $\begin{array}{l}\text { Speciality crops for Pacific } \\
\text { Island Agroforestry. }\end{array}$ & $\begin{array}{l}\text { Review of some crops for Pacific } \\
\text { Island Agroforestry. }\end{array}$ \\
\hline [31] & Jurgen and Buhler (2009) & $\begin{array}{l}\text { The manufacturing confectioner } \\
\text { cocoa processing. }\end{array}$ & $\begin{array}{l}\text { Cocoa beans processing in } \\
\text { confectionary industries. }\end{array}$ \\
\hline [32] & Lipp and Anklam (1998) & $\begin{array}{l}\text { Review of cocoa butter and alternative } \\
\text { fats for use in chocolate. }\end{array}$ & $\begin{array}{l}\text { Cocoa butter and alternative fats for use } \\
\text { in chocolate industries was reviewed. }\end{array}$ \\
\hline [33] & Whitefield (2005) & Making chocolates in the factory. & $\begin{array}{l}\text { The process of chocolate making } \\
\text { in the factory. }\end{array}$ \\
\hline
\end{tabular}

*From literature there is a gap of multi-criteria model and its software to be developed for decision making on processing machines' economic, engineering and productivity performance assessment. This led to this research. 
Table 2. Commonly used programming language and their comparison for selection.

\begin{tabular}{|c|c|c|c|c|c|}
\hline Criteria/PL & Java & Scale & $\mathrm{C}++$ & Haskell & VB.Net \\
\hline $\begin{array}{c}\text { Default More } \\
\text { Secured Programming } \\
\text { practice. }\end{array}$ & $\begin{array}{l}\text { Good secured } \\
\text { programming feature } \\
\text { with GC no pointers, } \\
\text { packages and thread. }\end{array}$ & $\begin{array}{l}\text { Good Default Security } \\
\text { with features like GC. } \\
\text { exception handling \& } \\
\text { works on JVM so uses } \\
\text { it security Manager. }\end{array}$ & $\begin{array}{l}\text { Not a secured } \\
\text { programming } \\
\text { language, buffer } \\
\text { overflow is not } \\
\text { detected. }\end{array}$ & $\begin{array}{l}\text { Good secured } \\
\text { programming features } \\
\text { with a GC, no pointer } \\
\text { and good type system. }\end{array}$ & $\begin{array}{l}\text { Built-in secure features } \\
\text { provided by .net and } \\
\text { programming itself } \\
\text { can implement } \\
\text { secure features. }\end{array}$ \\
\hline Web Application & $\begin{array}{l}\text { Quite popular for web } \\
\text { application abundant } \\
\text { libraries and services } \\
\text { serve this cause. }\end{array}$ & $\begin{array}{l}\text { Can develop, flexible, } \\
\text { highly scalable, secure } \\
\text { applications with help } \\
\text { of web development } \\
\text { frameworks. }\end{array}$ & $\begin{array}{l}\text { Used for stand } \\
\text { alone applications, } \\
\text { difficult to create } \\
\text { by default. }\end{array}$ & $\begin{array}{l}\text { Can develop the } \\
\text { application with } \\
\text { rich set libraries. }\end{array}$ & $\begin{array}{l}\text { Vb.net supports } \\
\text { web applications }\end{array}$ \\
\hline $\begin{array}{l}\text { Web Services } \\
\text { design and } \\
\text { Composition }\end{array}$ & $\begin{array}{l}\text { Good for web services } \\
\text { because of portability } \\
\text { and large number of } \\
\text { APIs and XML } \\
\text { available. }\end{array}$ & $\begin{array}{l}\text { RESTful services } \\
\text { provided with help } \\
\text { of frameworks. } \\
\text { Provisions of other } \\
\text { services still under } \\
\text { construction. XML } \\
\text { processing simple. }\end{array}$ & $\begin{array}{l}\text { Supports REST, XML, } \\
\text { WSO2 framework. }\end{array}$ & $\begin{array}{l}\text { Provide service like } \\
\text { SOAP and REST but } \\
\text { it is still immature in } \\
\text { terms of WSDL and } \\
\text { UDDI. }\end{array}$ & $\begin{array}{l}\mathrm{Vb} \text {, net can implement } \\
\text { web services such as } \\
\text { HTTP, SOAP, XML, } \\
\text { WSDL, UDDI and Net } \\
\text { remoting service can } \\
\text { implement itself. }\end{array}$ \\
\hline $\begin{array}{l}\text { Object-oriented base } \\
\text { Abstraction }\end{array}$ & $\begin{array}{l}\text { Primarily an object } \\
\text { oriented language } \\
\text { with powerful features. }\end{array}$ & $\begin{array}{l}\text { Supports two types } \\
\text { of abstractions. } \\
\text { Alternative to } \\
\text { functional abstraction. } \\
\text { Mainly used for } \\
\text { modeling families that } \\
\text { varies covariantly. }\end{array}$ & $\begin{array}{l}\text { Support Object } \\
\text { Oriented principles } \\
\text { but not as a default. }\end{array}$ & $\begin{array}{l}\text { Object Oriented } \\
\text { Concepts are not } \\
\text { supported by Haskell. } \\
\text { It requires an } \\
\text { extension called } \\
\text { OO Haskell }\end{array}$ & $\begin{array}{l}\text { Vb.net is an object } \\
\text { oriented language. } \\
\text { It supports OO } \\
\text { abstraction. }\end{array}$ \\
\hline Reflection & $\begin{array}{l}\text { Powerful reflection } \\
\text { mechanism. Supplies } \\
\text { a rich set of operations } \\
\text { for using metadata and } \\
\text { avoid complications. }\end{array}$ & $\begin{array}{l}\text { It's a subsystem. } \\
\text { Reflection API,. } \\
\text { Limited scope. } \\
\text { Modular, hence } \\
\text { reduce foot print \& } \\
\text { be efficient. }\end{array}$ & $\begin{array}{l}\text { Limited reflection } \\
\text { capabilities. }\end{array}$ & $\begin{array}{l}\text { Haskell does have } \\
\text { libraries for dynamics, } \\
\text { but they still do not } \\
\text { support complete } \\
\text { reflection. }\end{array}$ & $\begin{array}{l}\text { Vb, net supports } \\
\text { reflection using } \\
\text { Built-in called } \\
\text { "system reflection" }\end{array}$ \\
\hline $\begin{array}{l}\text { Aspect-Oriented } \\
\text { Programming }\end{array}$ & $\begin{array}{l}\text { Aspect, an extension } \\
\text { of JAVA treats AOP } \\
\text { concepts as first class } \\
\text { element of the } \\
\text { language. }\end{array}$ & $\begin{array}{l}\text { Provides } 2 \text { different } \\
\text { types. Mainly, Mixin } \\
\text { composition stacks. }\end{array}$ & $\begin{array}{l}\text { With static type } \\
\text { of language it is } \\
\text { difficult, Aspect } \\
\text { C++ supports it. }\end{array}$ & $\begin{array}{l}\text { Does not directly } \\
\text { support. Has an } \\
\text { extension called } \\
\text { AOP Haskell. }\end{array}$ & $\begin{array}{l}\text { AOP Engine in NET } \\
\text { to implement AOP } \\
\text { programming but } \\
\text { it supports only } \\
\text { at run time. }\end{array}$ \\
\hline $\begin{array}{c}\text { Functional } \\
\text { Programming }\end{array}$ & $\begin{array}{l}\text { No functional instead } \\
\text { uses interfaces \& inner } \\
\text { classes it is fairly easy } \\
\text { to mimic some } \\
\text { features of FP }\end{array}$ & $\begin{array}{l}\text { Powerful support } \\
\text { and well suited. } \\
\text { Light weight sytax. } \\
\text { Support High-order, } \\
\text { nested function, } \\
\text { and currying. }\end{array}$ & $\begin{array}{l}\text { Doesn't support } \\
\text { to fuller extent } \\
\text { but can be done } \\
\text { using FC++. }\end{array}$ & $\begin{array}{c}\text { This is a functional } \\
\text { programming } \\
\text { language. }\end{array}$ & $\begin{array}{l}\text { Vb.net is not a } \\
\text { pure functional } \\
\text { programming but } \\
\text { it supports Lambda } \\
\text { Calculus. }\end{array}$ \\
\hline $\begin{array}{c}\text { Declarative } \\
\text { Programming }\end{array}$ & $\begin{array}{c}\text { Library like JsetL } \\
\text { and Jsolver offer a } \\
\text { number of facilities to } \\
\text { support DP. }\end{array}$ & $\begin{array}{c}\text { Uses a prolog } \\
\text { interpreter called scale } \\
\text { Logic. Emphasises } \\
\text { on simplicity and not } \\
\text { performance. }\end{array}$ & $\begin{array}{l}\text { By default not } \\
\text { possible but } \\
\text { merging prolog } \\
\text { is an alternative. }\end{array}$ & $\begin{array}{l}\text { Haskell, one can use } \\
\text { Monards to implement } \\
\text { Declarative Logic } \\
\text { Programming. }\end{array}$ & $\begin{array}{l}\text { Doesn't implement } \\
\text { declarative } \\
\text { programming } \\
\text { by itself. }\end{array}$ \\
\hline
\end{tabular}




\section{Continued}

\begin{tabular}{|c|c|c|c|c|c|}
\hline Batch Scripting & $\begin{array}{l}\text { Easy, involve the use } \\
\text { of two JAVA classes. } \\
\text { The Run time class } \\
\text { and process class. }\end{array}$ & $\begin{array}{c}\text { Support } \\
\text { Batch/Bash/Perl } \\
\text { scripting language. }\end{array}$ & $\begin{array}{l}\text { Including libraries } \\
\text { allows to do so. } \\
\text { But decreases } \\
\text { performance. }\end{array}$ & $\begin{array}{l}\text { Shell scripting is } \\
\text { possible with Haskell } \\
\text { using HSH. }\end{array}$ & $\begin{array}{l}\text { Vb.net supports batch } \\
\text { scripting and macros. }\end{array}$ \\
\hline UI protype design & $\begin{array}{l}\text { Rich set of libraries } \\
\text { for UI applications } \\
\text { but the code is } \\
\text { verbose and can } \\
\text { be mysterious for } \\
\text { stakeholders. }\end{array}$ & $\begin{array}{l}\text { Support UI with } \\
\text { basis on JAVA } \\
\text { swing framework } \\
\text { but hides much } \\
\text { of its complexity. }\end{array}$ & $\begin{array}{c}\text { Difficult to } \\
\text { implement by } \\
\text { defaults but supports } \\
\text { some libraries. }\end{array}$ & $\begin{array}{l}\text { Has rich set of } \\
\text { libraries for GUI } \\
\text { applications. }\end{array}$ & $\begin{array}{l}\text { Vb.net supports rich } \\
\text { UI interfaces and IDE } \\
\text { give good support } \\
\text { to programmers. }\end{array}$ \\
\hline
\end{tabular}

Source: [34] [35].

$$
\begin{aligned}
\text { Cost Effective Index } & =\frac{\text { Productivity for Current Period }}{\text { Productivity for the base Period }} \\
W_{c} & =\frac{\sum Q_{2} P_{2} / \sum Q_{1} P_{1}}{\sum I_{2} C_{2} / \sum I_{1} C_{1}}
\end{aligned}
$$

It is to be noted that cost effectiveness index is product of factor productivity index and price recovery index. The developed software interface is as shown in Figure 1.

\section{Results and Discussions}

The data collected for the running of the models and the software developed ran through period of ten (10) years from 2008 to 2017. Application of the software using the three selected strategic decisions on windowing machine, for each year 2008 to 2017 gave the results shown in Table 3.

Table 3 shows summary of each year performance of winnowing machine on each of the selected strategic decisions from 2008 to 2017. The performance as it affects the machine annual operating cost (MAOC), overall machine effectiveness (MEFF) and cost effective index (CEI) were shown in Table 3. These results were statistically analysed and the results' graphs were shown in Figures 2-5, and Figure 6, respectively.

Figure 2 and Figure 3 show the mathematical model of the MAOC over the period of 10 years on the MAOC. The plot was modeled using a polynomial equation of one degree which gave us

$$
f(x)=p 1 * x+p 2
$$

where: $P_{1}=0.056$ and $P_{2}=-112.2$. This example shows how to fit polynomials up to one degree to the available MAOC data for the period of 10 years on the Windowing machine figures that correspond to the error (SSE) and the adjusted R-square statistics to help determine the best fit.cross zero on the p1 and p2 coefficients for the first-degree polynomial. 
Decision Support System

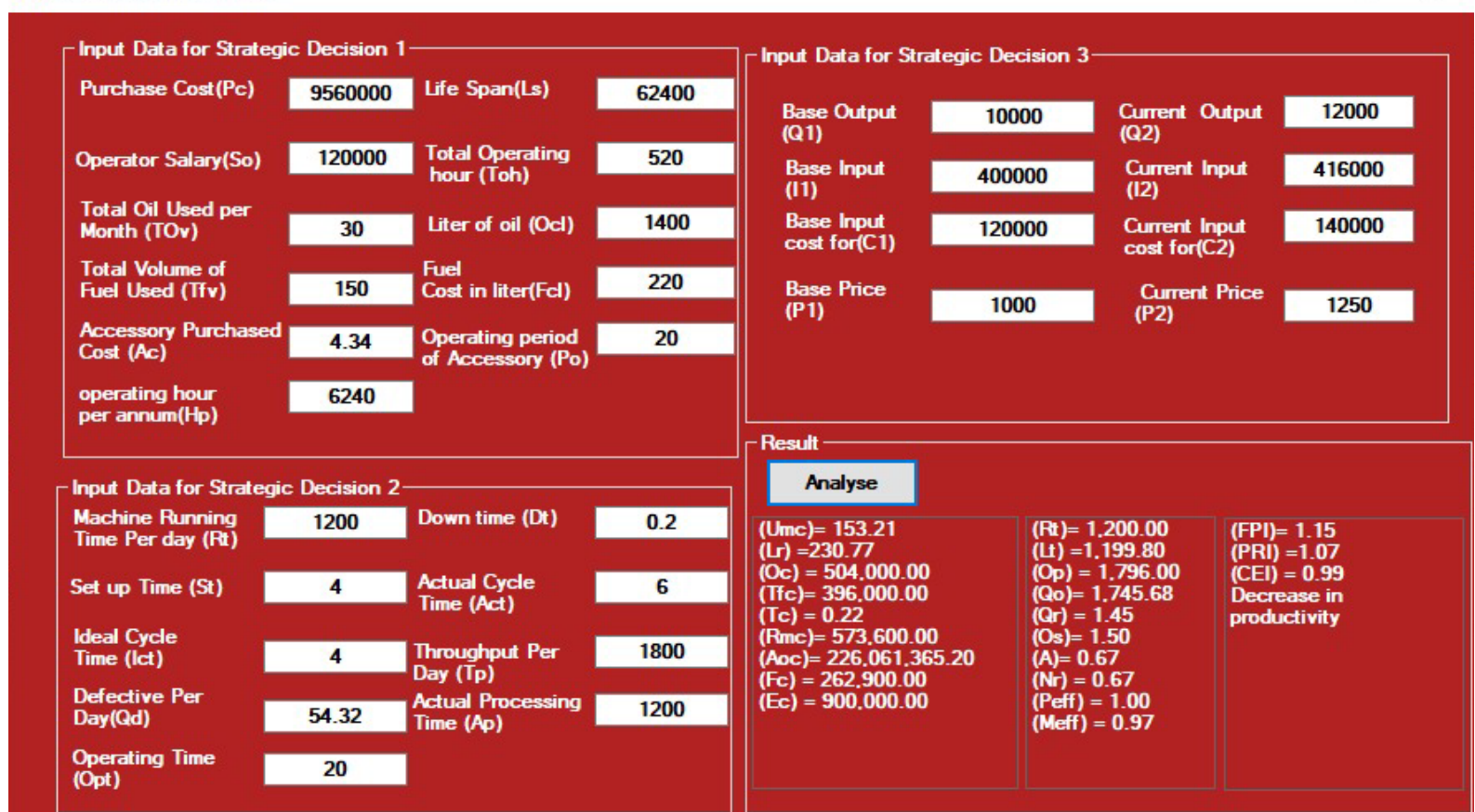

Figure 1. Interface for data collection, analysis and results generation.

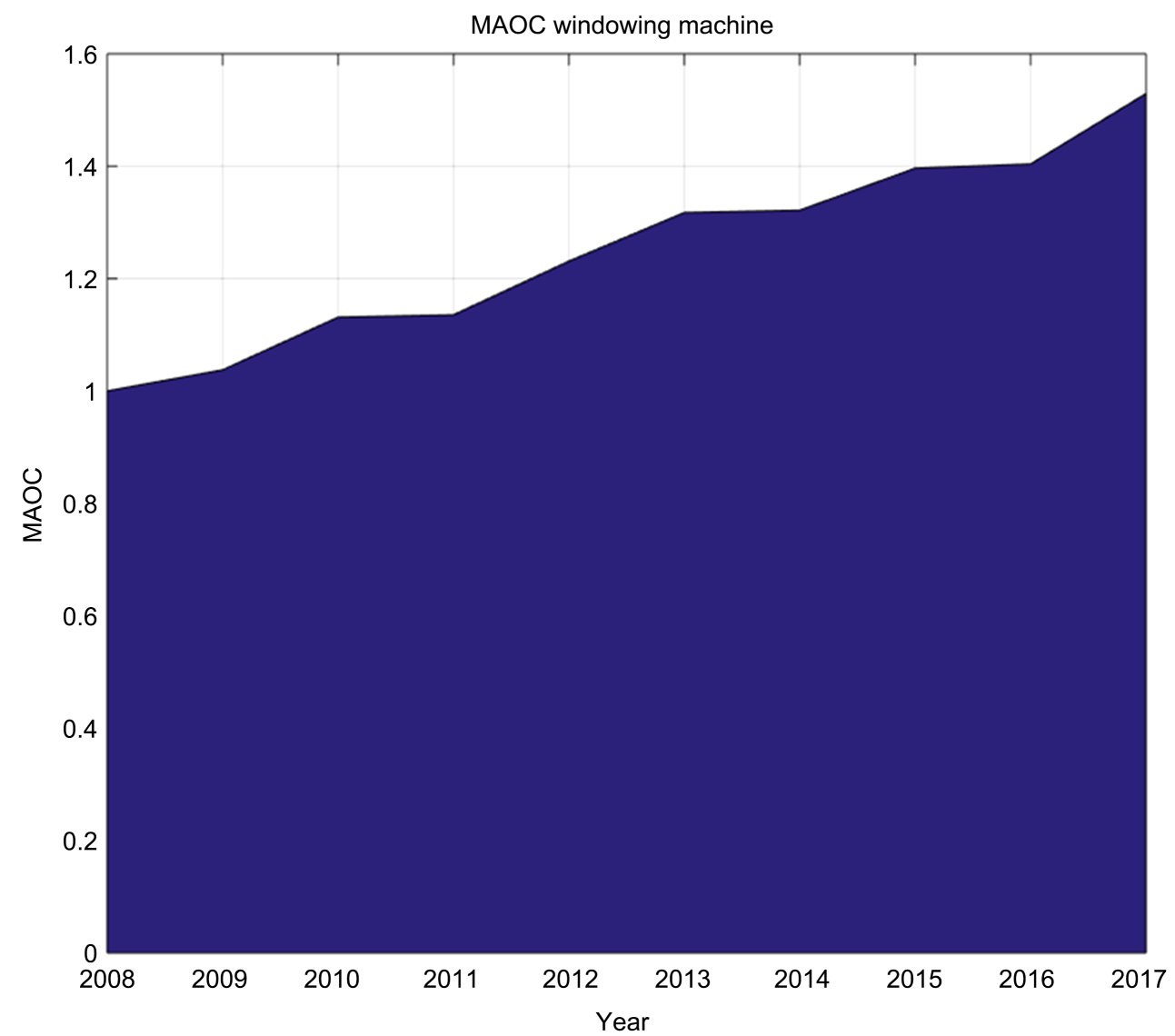

Figure 2. Statistical analysis of windowing machine performance on Machine Annual Operating Cost (MAOC) from 2008 till 2017. 


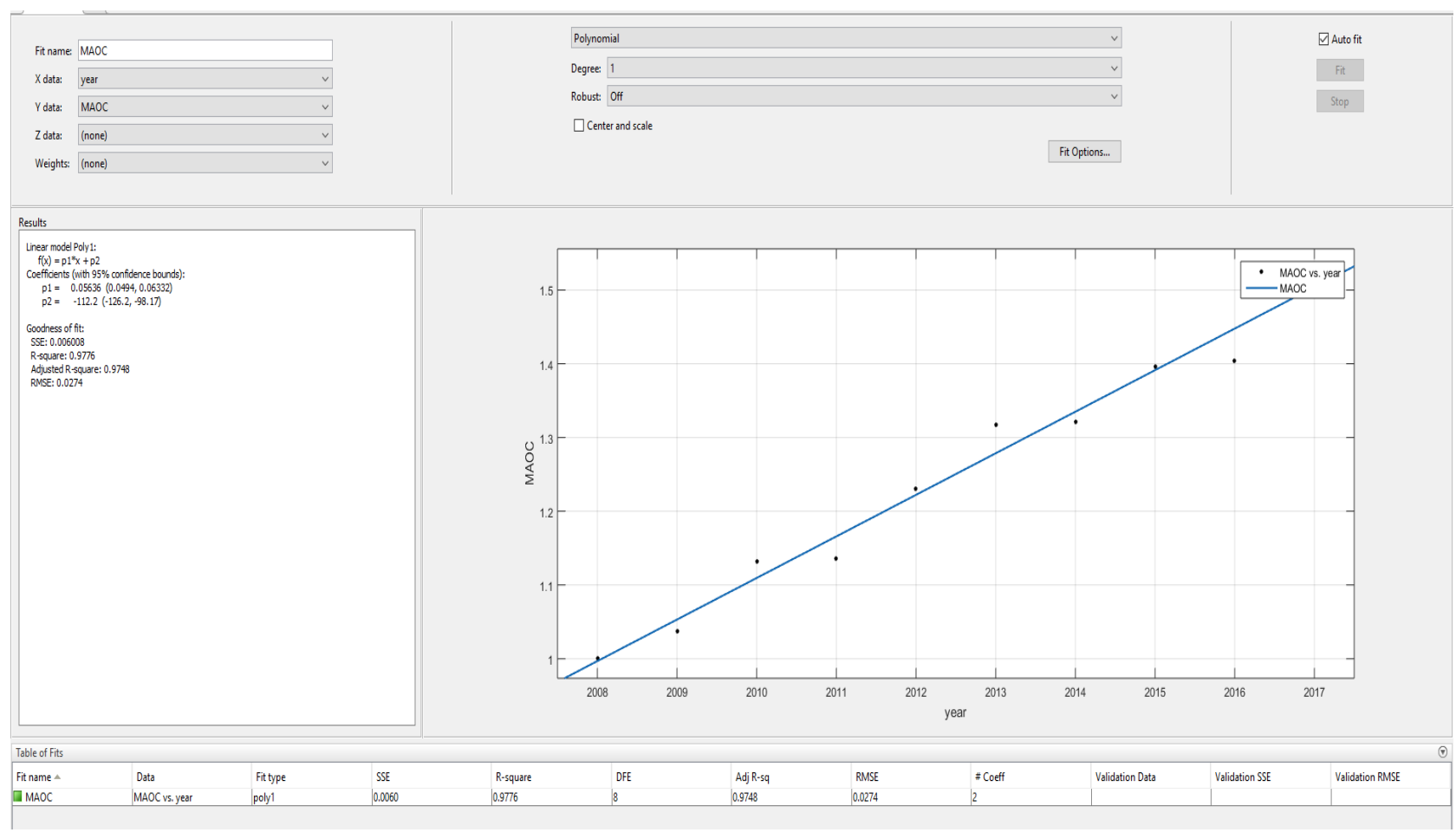

Figure 3. Determination of the model fittings Using R-Square Test.

Table 3. Yearly windowing machine's performance on each strategic decision (AOC, MEFF and CEI) from 2008 to 2017. The bolded 2008 results were seen on the computer interface developed.

\begin{tabular}{|c|c|c|c|}
\hline & $\mathrm{AOC}$ & Meff & CEI \\
\hline \multicolumn{2}{|c|}{ Windowing Machine } & & \\
\hline 2008 & 226061365.2 & 0.97 & 0.99 \\
\hline 2009 & 234536333.2 & 0.89 & 1.09 \\
\hline 2010 & 255735333.2 & 0.91 & 0.8 \\
\hline 2011 & 256678487.2 & 0.97 & 0.78 \\
\hline 2012 & 278272629.2 & 0.94 & 0.97 \\
\hline 2013 & 297837365.2 & 0.92 & 1.14 \\
\hline 2014 & 298761553.2 & 0.98 & 1.02 \\
\hline 2015 & 315673833.2 & 0.95 & 1.11 \\
\hline 2016 & 317365433.2 & 0.87 & 0.81 \\
\hline 2017 & 345721365.2 & 0.86 & 0.96 \\
\hline
\end{tabular}




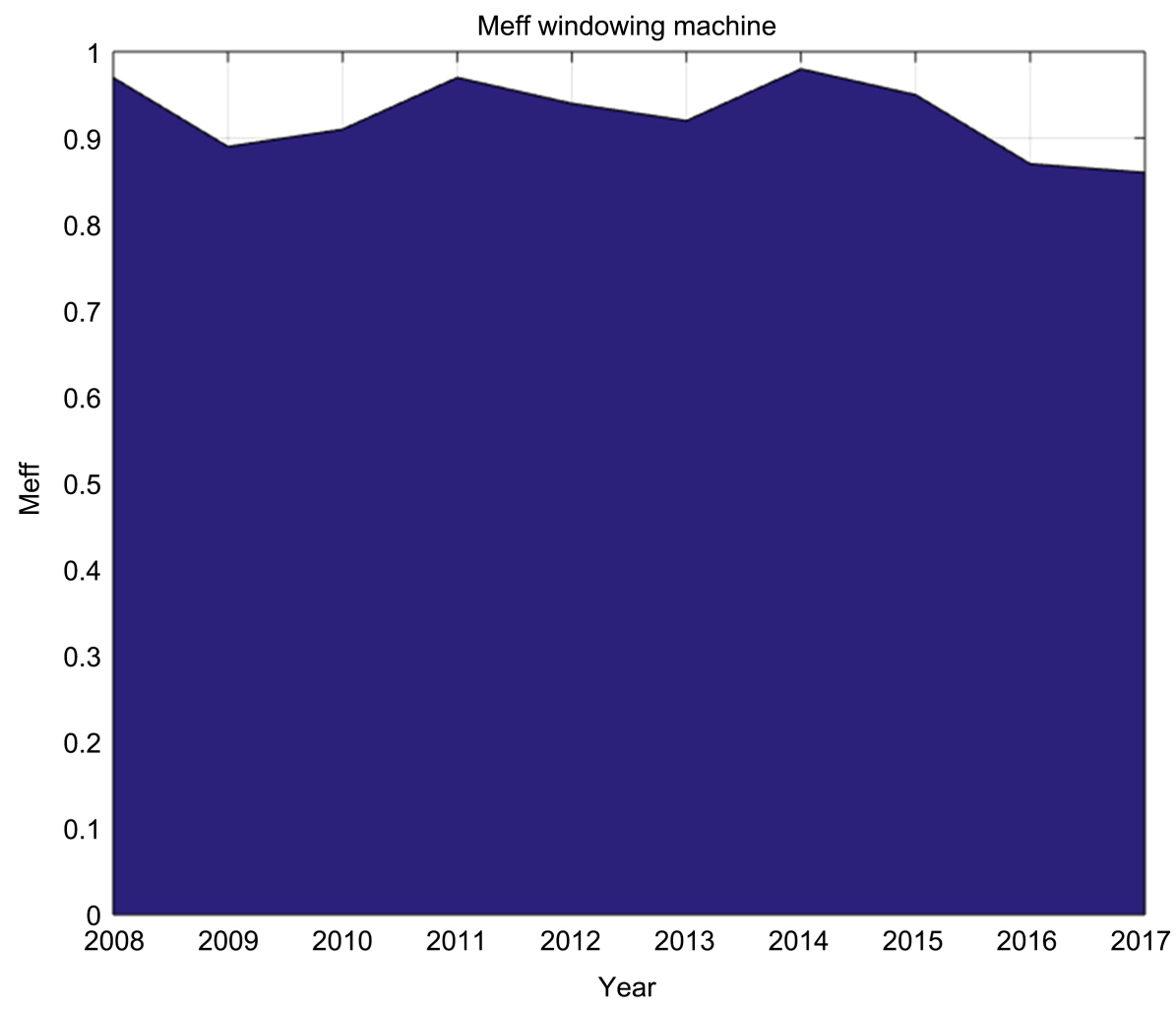

Figure 4. Statistical analysis of windowing machine performance on Machine Effectiveness (MEFF) from 2008 till 2017.

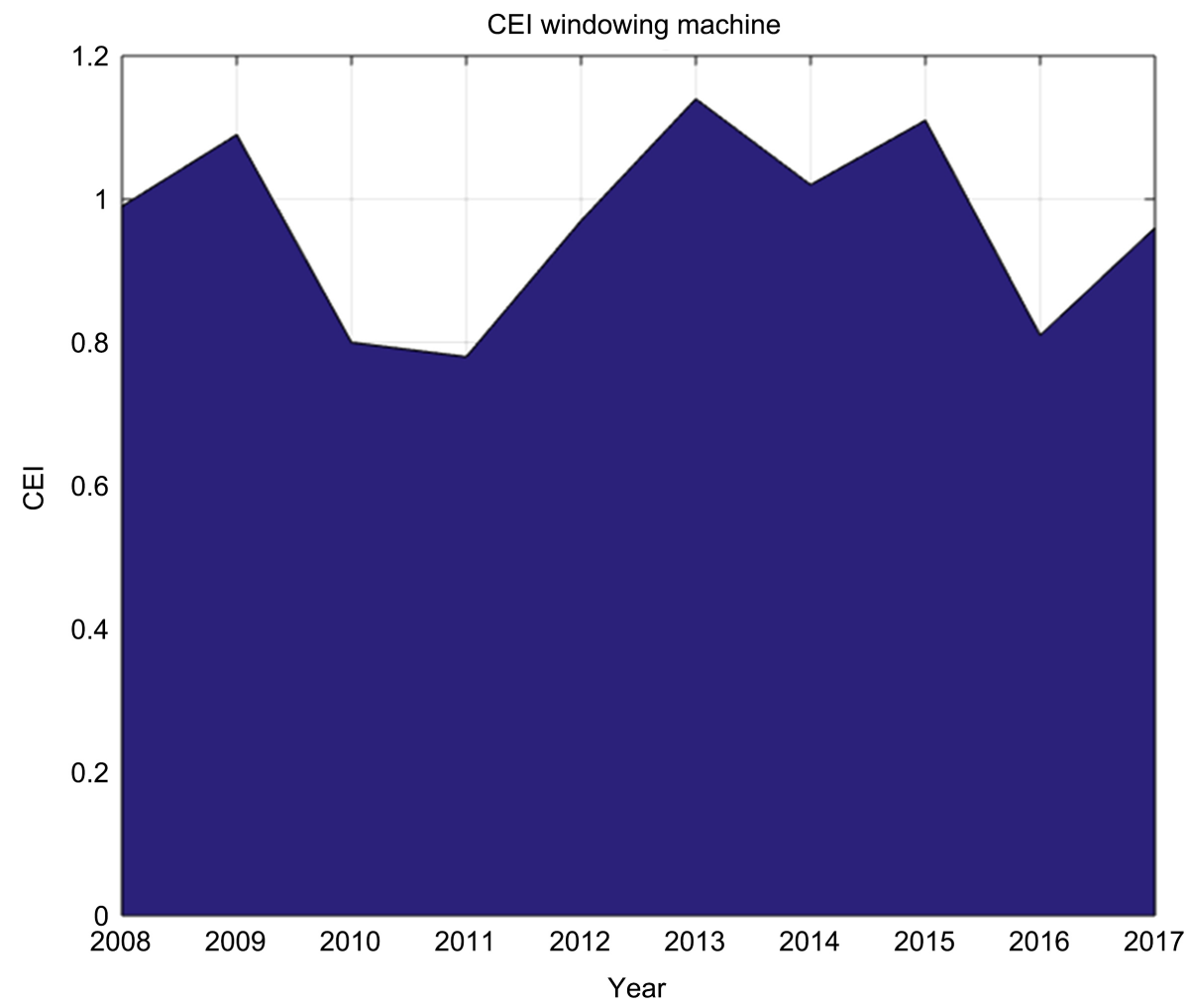

Figure 5. Statistical analysis of windowing machine performance on machine Cost Effective Index (CEI) from 2008 till 2017. 


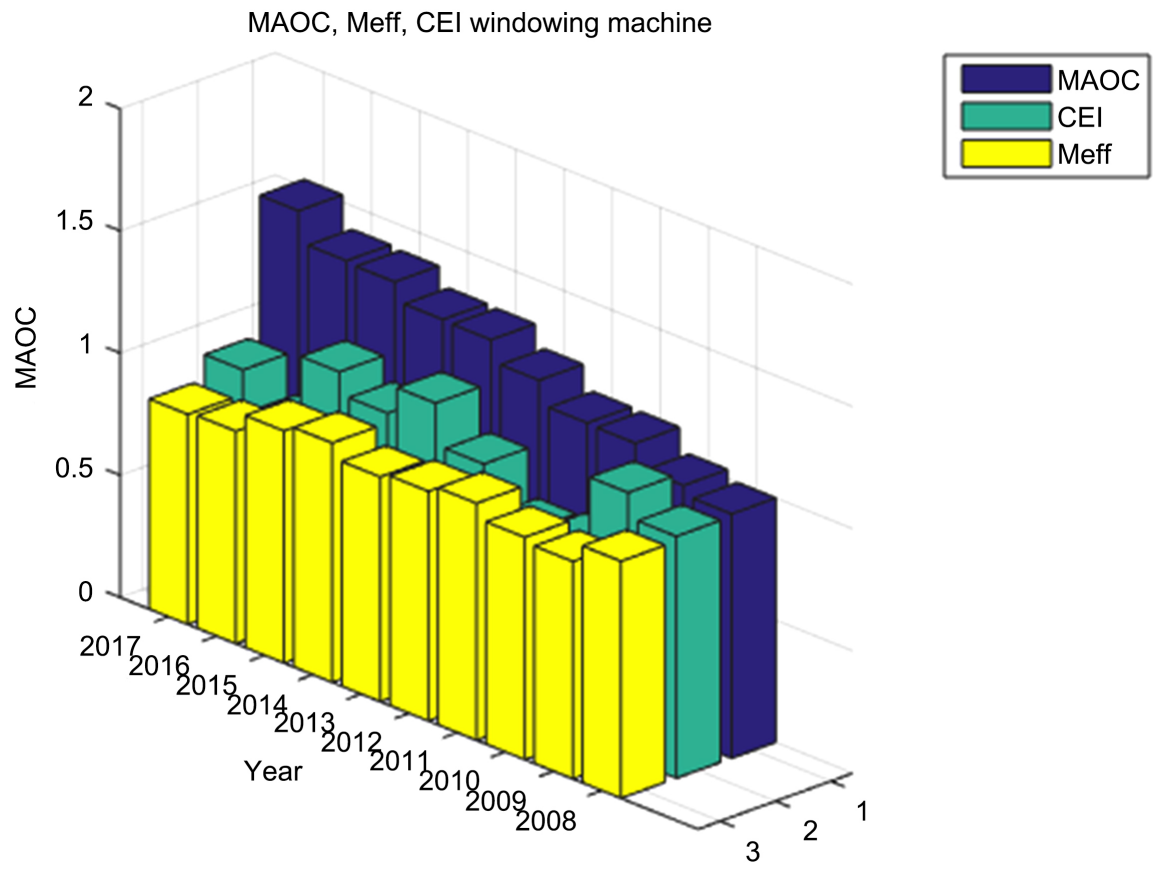

Figure 6. The 3D bar chart of MAOC, CEI and MEFF over the period of 10 years (2008-2017).

The model has a fitting of $97.76 \%$ according to R-Square test and the Sum of square error was given as 0.006 which is approximately 0 . With this model we can actually predict the following year MAOC if all necessary factors are constant.

Figure 4 represents the machine operating effectiveness of the windowing machine over the period of 2008 to 2009 it has a very good flow with average effectiveness of $92.6 \%$ with variance of 0.0018 . The average effectiveness of the machine varies over the years however the minimal effectiveness which is occurred in 2017 still has a very good effectiveness of $86 \%$ this is above the acceptable low limit of $85 \%$.

Figure 5 represents the area chart of the cost effective index. Initially in 2008 the CEI is very close to 1 which means the operating cost of the windowing machine was performing well on budget. In 2009 the operating cost was performing well against budget. But 2010, 2011 and 2016 the windowing machine was over budgeted

Figure 6 represents the 3D bar chart of MAOC, CEI and Meff over the period of 10 years (2008-2017) to show the exact value of MAOC, CEI and Meff because area chart are known to show a trend over a particular period and not the exact value

Source Code For The Software Development.

Public Class Form 1

Private Sub Analyse_Click(sender As Object, e As EventArgs) Handles Analyse.Click

'calculation for SD1 
'FC cal

Dim FC, Um, RMs, Lr, Oc, Tfc, Tc, Ec, SD1 As Double

$\mathrm{FC}=\mathrm{Val}\left(\mathrm{sd} 1 \_\right.$pc.Text $){ }^{*} 0.0275$

$\mathrm{Um}=\mathrm{Val}\left(\mathrm{sd} 1 \_\right.$pc.Text $) / \mathrm{Val}\left(\mathrm{sd} 1 \_\right.$ls.Text $)$

$\mathrm{RMs}=0.06^{*} \mathrm{Val}\left(\mathrm{sd} 1 \_\mathrm{pc} . \text { Text }\right)^{\star}{ }^{\star} \mathrm{Val}\left(\mathrm{sd} 1 \_\right.$hp.Text $)$

$\mathrm{Lr}=\mathrm{Val}\left(\mathrm{sd} 1 \_\right.$so.Text) $/ \mathrm{Val}\left(\mathrm{sd} 1 \_\right.$toh.Text $)$

$\mathrm{Oc}=\mathrm{Val}(\mathrm{sd} 1$ _tov.Text $){ }^{*} \mathrm{Val}(\mathrm{sd} 1$ _ocl.Text $){ }^{*} 12$

$\mathrm{Tfc}=\mathrm{Val}\left(\mathrm{sd} 1 \_t \mathrm{ff} . \mathrm{Text}\right){ }^{*} \mathrm{Val}\left(\mathrm{sd} 1 \_\mathrm{fcl} . \mathrm{Text}\right){ }^{\star} 12$

$\mathrm{Tc}=\mathrm{Val}\left(\mathrm{sd} 1 \_\right.$ac.Text $) / \mathrm{Val}\left(\mathrm{sd} 1 \_\right.$po.Text $)$

$\mathrm{Ec}=\mathrm{Tfc}+\mathrm{Oc}$

$\mathrm{SD} 1=\mathrm{FC}+\left(\mathrm{Um}^{*}(\mathrm{RMs}+\mathrm{Lr}+\mathrm{Ec}+\mathrm{Tc})\right)$

Console.WriteLine("FC\%= " \& FC.ToString)

Result1.Text $="(\mathrm{Umc})=" \&$ FormatNumber $(\mathrm{Um}, 2)$.ToString \& vbCrLf \& "(Lr) =" \& FormatNumber $($ Lr, 2).ToString \& vbCrLf \& "(Oc) = " \& FormatNumber(Oc, 2).ToString \& vbCrLf \& "(Tfc)= " \& FormatNumber(Tfc, 2).ToString \& vbCrLf \& "(Tc) = " \& FormatNumber(Tc, 2). ToString \& vbCrLf \& $"(\mathrm{Rmc})=$ " \& FormatNumber(RMs, 2).ToString \& vbCrLf \& "(Aoc)= " \& FormatNumber(SD1, 2).ToString \& vbCrLf \& $"(\mathrm{Fc})=" \&$ FormatNumber(FC, 2).ToString \& vbCrLf \& "(Ec) = " \& FormatNumber(Ec, 2). ToString

'calculation for SD2

Dim A_bar, opt, speed, efficiency, N_bar, epsilon, SD2 As Double

Dim Rt As Double = Val(sd2_rt.Text)

$\operatorname{Dim} \mathrm{Lt}=\mathrm{Rt}-\mathrm{Val}\left(\mathrm{sd} 2 \_\mathrm{lt}\right.$.Text)

Dim Qo As Double $=(\operatorname{Val}($ sd2_tp.Text $)-$ Val(sd2_qd.Text $))$

opt $=$ Val(sd2_tp.Text) - Val(sd2_st.Text)

A_bar $=$ Val(sd2_rt.Text) $/$ opt

speed $=\mathrm{Val}($ sd2_act.Text $) / \mathrm{Val}\left(\mathrm{sd} 2 \_\right.$lct.Text $)$

N_bar $=$ Val(sd2_ap.Text) $/$ opt

efficiency $=$ speed ${ }^{\star}$ N_bar

epsilon $=\left(\mathrm{Val}\left(\mathrm{sd} 2 \_t \mathrm{t}\right.\right.$. Text $)-\mathrm{Val}\left(\mathrm{sd} 2 \_\mathrm{qd} . T\right.$ ext $\left.)\right) / \mathrm{Val}\left(\mathrm{sd} 2 \_r t . T e x t\right)$

SD2 = A_bar * efficiency * epsilon

Console.WriteLine(SD2.ToString)

If $(\mathrm{SD} 2<0.85)$ Then

If $($ A_bar < 0.9) Then

$\mathrm{Rt}=0.9$ * opt

A_bar $=$ Rt / opt

End If

If (efficiency < 0.95) Then

Dim n_constant As Double $=0.8$

efficiency $=$ speed ${ }^{\star}\left(0.95 / \mathrm{n} \_\right.$constant $)$

End If

efficiency $=$ speed ${ }^{\star}$ N_bar

If (epsilon < 0.89) Then 
epsilon $=(\operatorname{Val}($ sd2_tp.Text $)-\operatorname{Val}(0.89 * \operatorname{Val}($ sd2_rt.Text $))) /$

Val(sd2_rt.Text)

End If

SD2 = A_bar * efficiency * epsilon

End If

Result2.Text $="(\mathrm{Rt})="$ \& FormatNumber(Rt, 2).ToString \& vbCrLf \& $"(\mathrm{Lt})=$ " \& FormatNumber(Lt, 2).ToString \& vbCrLf \& "(Op) = " \& FormatNumber(opt, 2).ToString \& vbCrLf \& "(Qo)= " \& FormatNumber(Qo, 2).ToString \& vbCrLf \& $"(\mathrm{Qr})=$ " \& FormatNumber(epsilon, 2).ToString \& vbCrLf \& "(Os)= " \& FormatNumber(speed, 2).ToString \& vbCrLf \& "(A)= " \& FormatNumber(A_bar, 2).ToString \& vbCrLf \& "(Nr) = " \& FormatNumber(N_bar, 2).ToString \& vbCrLf \& "(Peff) = " \& FormatNumber(efficiency, 2).ToString \& vbCrLf \& "(Meff) = " \& FormatNumber(SD2, 2).ToString

'SD3 computation

Dim mpi, pri, cei, pf, fpi As Double

Dim fina As String

'mpi $=(\operatorname{Val}($ sd3_a1.Text $) / \operatorname{Val}($ sd3_a2.Text $))$

pri $=\left(\left(\operatorname{Val}(\right.\right.$ sd3_Q2.Text $) * \operatorname{Val}\left(\mathrm{sd} 3 \_\right.$p2.Text $\left.)\right) /\left(\mathrm{Val}\left(\mathrm{sd} 3 \_\mathrm{Q} 2 . T e x t\right) *\right.$

$\operatorname{Val}($ sd3_p1.Text $))) /\left(\left(\operatorname{Val}\left(\mathrm{sd} 3 \_I 2 . T e x t\right) * \operatorname{Val}\left(\mathrm{sd} 3 \_c 2 . T e x t\right)\right) /\left(\mathrm{Val}\left(\mathrm{sd} 3 \_I 2 . T e x t\right)\right.\right.$

* $\operatorname{Val}($ sd3_c1.Text))) cei $=\left(\left(\operatorname{Val}(\right.\right.$ sd3_Q2.Text $\left.){ }^{*} \operatorname{Val}\left(\mathrm{sd} 3 \_p 1 . T e x t\right)\right) /\left(\operatorname{Val}\left(\mathrm{sd} 3 \_\mathrm{Q} 1 . T e x t\right) *\right.$

$\left.\left.\mathrm{Val}\left(\mathrm{sd} 3 \_\mathrm{p} 1 . \mathrm{Text}\right)\right)\right) /\left(\left(\mathrm{Val}\left(\mathrm{sd} 3 \_I 2 . T e x t\right) * \mathrm{Val}\left(\mathrm{sd} 3 \_\mathrm{c} 2 . \mathrm{Text}\right)\right) /\left(\mathrm{Val}\left(\mathrm{sd} 3 \_I 1 . T e x t\right)\right.\right.$

* Val(sd3_c1.Text)))

fpi $=\left(\left(\operatorname{Val}(\right.\right.$ sd3_Q2.Text $\left.) * \operatorname{Val}\left(\mathrm{sd} 3 \_p 1 . T e x t\right)\right) /\left(\operatorname{Val}\left(\mathrm{sd} 3 \_\mathrm{Q} 1 . T e x t\right) *\right.$

$\left.\left.\mathrm{Val}\left(\mathrm{sd} 3 \_\mathrm{p} 1 . \mathrm{Text}\right)\right)\right) /\left(\left(\mathrm{Val}\left(\mathrm{sd} 3 \_I 2 . T e x t\right) * \mathrm{Val}\left(\mathrm{sd} 3 \_\mathrm{c} 1 . \mathrm{Text}\right)\right) /\left(\mathrm{Val}\left(\mathrm{sd} 3 \_I 1 . T e x t\right)\right.\right.$

* $\operatorname{Val}($ sd3_c1.Text)))

$\mathrm{pf}=\mathrm{cei} / \mathrm{pri}$

If $(\mathrm{pf}=\mathrm{pri})$ Then

fina $=$ "Static productivity"

ElseIf pf $>$ pri Then

fina $=$ "increase In productivity"

Else

fina $=$ "Decrease in productivity"

End If

Result3.Text $=$ "(FPI $)="$ \& FormatNumber(fpi, 2).ToString \& vbCrLf $\&$ "(PRI) =" \& FormatNumber(pri, 2).ToString \& vbCrLf \& "(CEI) = " \& FormatNumber(cei, 2).ToString \& vbCrLf \& fina

End Sub

End Class

\section{Conclusion}

The objectives which are computer algorithm and software development for the models' implementation were achieved and source code written for the model's 
ease of application using JAVA programming language due to its flexibility and friendliness was also achieved. The cost benefit, was successfully determined by comparing the cost of foreign software of nearly similar functions with limitation of single criterion with this of multi-criteria cost and the software was able to make a saving cost of $40 \%$ based on the average cost of the six software collected from the internet. The tool was able to consider arms of Economic, Engineering and Productivity features, of production processes, in an attempt to reduce/eliminate all barriers that could hinder optimal performance. The outcome contributed to the existing knowledge in the field of Industrial Engineering and in particular decision making in machine operating cost, overall machine effectiveness for productivity enhancement and machine operations' cost effective index to determine the machine's ability to fight inflation.

\section{Acknowledgements}

The research team hereby acknowledged the Managing Director of Hurlag Technologies limited, 32A Ladipo Oluwole Street, Ikeja, Lagos for both their technical and financial support that made this research a success.

\section{Conflicts of Interest}

The authors declare no conflicts of interest regarding the publication of this paper.

\section{References}

[1] Mogaji, P.B., Akinnuli, B.O., Awopetu, O.O. and Olagunju, O.R. (2020) Modeling Economic Dominant Feature for Agro-Oil Seeds Processing Machinery Performance Evaluation. International Journal of Industrial Engineering \& Technology, 10, 11-20.

[2] Akinnuli, B.O. and Oluwadare, S.A. (2011) Computer Aided System for Modelling Machinery Procurement due Date Prediction in Production Industries. Journal of Information Computer Technology, 10, 99-115. https://doi.org/10.32890/jict.10.2011.8111

[3] Goering, C., Stone, M., Smith, D. and Turnquist, P. (2006) Off-Road Vehicle Engineering Principles. American Society of Agricultural Engineers, St. Joseph.

[4] Srivastava, A., Goering, C., Rohrbach, R. and Buckmaster, D. (2006) Engineering Principles of Agricultural Machinery. American Society of Agricultural and Biological Engineers, St. Joseph.

[5] Goering, C. and Hansen, A. (2008) Engine and Tractor Power. American Society of Agricultural and Biological Engineers, St. Joseph.

[6] Yule, I.J., Kohnen, G. and Nowak, M. (1999) A Tractor Performance Monitor with DGPS Capability. Computers and Electronics in Agriculture, 23, 155-174. https://doi.org/10.1016/S0168-1699(99)00029-0

[7] Schmidt, J.P., Taylor, R.K. and Gehl, R.J. (2003) Developing Topographic Maps Using a Sub-Meter Accuracy Global Positioning Receiver. Applied Engineering in Agriculture, 19, 291-300. https://doi.org/10.13031/2013.13661

[8] Boon, N.E., Yahya, A., Kheiralla, A.F., Wee, B.S. and Gew, S.K. (2005) A Trac- 
tor-Mounted, Automated Soil Penetrometer-Shearometer Unit for Mapping Soil Mechanical Properties. Biosystems Engineering, 90, 381-396.

https://doi.org/10.1016/j.biosystemseng.2004.12.004

[9] Yahya, A., Zohadie, M., Kheiralla, A.F., Giew, S.K. and Boon, N.E. (2009) Mapping System for Tractor-Implement Performance. Computers and Electronics in Agriculture, 69, 2-11. https://doi.org/10.1016/j.compag.2009.06.010

[10] Singh, C.D. and Singh, R.C. (2011) Computerized Instrumentation System for Monitoring the Tractor Performance in the Field. Journal of Terramechanics, 48, 333-338. https://doi.org/10.1016/j.jterra.2011.06.007

[11] Akinnuli, B.O. and Babalola, S.A. (2013) Computer-Aided System for Determining Industrial Machinery Optimal Replacement Period. Journal of Information and Communication Technology, 12, 175-188.

https://doi.org/10.32890/jict.12.2013.8143

[12] Agritrade, Executive Brief: The Cocoa Sector in ACP-EU Trade, October 2009. 6.

[13] Bruce, C.H. (2006) Best Practices in Maintenance. http://www.tpmonline.com/articles_on_total_productive_maintenance/management

[14] Diwlworth, J.B. (2013) Production and Operations Management. McGraw-Hill, New York.

[15] Kadiri, M.A. (2000) Scheduling of Preventive Maintenance in a Manufacturing Company: A Computer Model Approach. Unpublished M.Sc. Thesis, Department of Industrial and Production Engineering, University of Ibadan, Ibadan.

[16] Oluwadare, S.A. and Akinnuli, B.O. (2012) A Mixed Linear Programming Model for Real-Time Task Scheduling in Multiprocessor Computer System. Journal of Information and Communication Technology, 11, 17-36.

[17] Cerpa, H.C. and Verner, F.T. (1996) Making Chocolate from Scratch. FSandT-33. CTAHR, University of Hawai' $i$, Honolulu.

[18] Hamundu, F.M., Wibowo, S. and Budiarto (2012) A Hybrid Fuzzy-Monte Carlo Simulation Approach for Economical Assessment of the Impact of ERP Technology. Journal of Information and Communication Technology, 12, 93-111.

[19] Akinnuli, B.O., Ayodeji, S.P. and Omeiza, A.J. (2014) Computer Aided Design for Cocoa Beans Processing Yield Prediction. International Journal of Applies Science and Technology, 4, 8-91.

[20] Akinnuli, B.O., Bekunmi, O.S. and Osueke, C.O. (2015) Design Concept towards Cocoa Winnowing Mechanization for Nibs Production in Manufacturing Industries. British Journal of Applied Science and Technology, 161, 35-45. https://doi.org/10.9734/BJAST/2015/16161

[21] Adzimah, S.K. and Asiam, E.K. (2010) Design of a Cocoa Pod Splitting Machine. Research Journal of Applied Sciences, Engineering and Technology, 2, 622-634.

[22] Arai, N. and Iwata, S.T. (1997) Cocoa Crop Protection: An Expert Forecast on Future Progress, Research Priorities and Policy with the Help of the Delphi Survey. Crop Protection, 16, 227-233. https://doi.org/10.1016/S0261-2194(96)00099-3

[23] Audu, I., Oloso, A.O. and Umar, B. (2004) Development of a Concentric Cylinder Locust Bean Dehuller. Agricultural Engineering International, 6, 14-19.

[24] Awua, P.K. (2002) Cocoa Processing and Chocolate Manufacture in Ghana. David Jamieson and Associates Press Inc., Essex, 12-14.

[25] Bjarnemo, B.O. and Hansen, R.C. (1998) Overall Equipment Effectiveness (OEE). Industrial Press, Italy. 
[26] Bozzo, F.T. and Harrison, J.R. (1998) Dominant Coalition Dynamics, the Politics of Organizational Adaptation and Failure. International Conference on Computer Simulation and the Social Science, Cortona.

[27] EEC (1973) Directive 73/241/EEC by European Parliament and the European Council Relating to Cocoa and Chocolate Products Intended for Human Consumption. Official Journal of the European Communities, L228, 23-35.

[28] Faborode, M.O. and Oladosun, G.A. (1991) Development of a Cocoa Pod-Processing Machine. Nigerian Engineers, 26, 26-31.

[29] Harrington, S.F. (1998) Cultivating Cacao: Implications of Sun-Grown Cacao on Local Food Security and Environmental Sustainability. Agriculture and Human Values, 20, 277-285.

[30] World Cocoa Foundation Scientific Research and Website Library. http://www.worldcocoafoundation.org

[31] Jurgen, F. and Buhler, B. (2009) The Manufacturing Confectioner September, Cocoa Processing. Cleaning through Roasting.

[32] Lipp, M. and Anklam, E. (1998) Review of Cocoa Butter and Alternative Fats for Use in Chocolate-Part A. Compositional Data. Food Chemistry, 62, 73-79. https://doi.org/10.1016/S0308-8146(97)00160-X

[33] Whitefield, R. (2005) Making Chocolates in the Factory. Kenedy's Publications Ltd., London.

[34] Oluwadare, S.A. and Akinnuli, B.O. (2012) A Mixed Integer Linear Programming Model for Real-Time Task Scheduling in Multiprocessor Computer System. Journal of Information and Communication Technology, 12, 17-36.

[35] Weipedia Scala. http://en.wikipedia.org/wiki/Scala_(programming_language) 